\title{
LEVÉL PLÉH CSABÁNAK KARÁCSONY SÁNDOR-EMLÉKEZET(ÜNK) ÉS A MAGYAR PSZICHOLÓGIATÖRTÉNET-ÍRÁS
}

\section{Kedves Csaba!}

A Magyar Pszichológiai Szemle 2018. évi 2. számában egy figyelemre méltó recenziót írtál a Heltai Miklós és általam szerkesztett Karácsony Sándor és a magyar pszichológia c. konferenciakötetünkrôl (Pléh, 2018). Recenziód valóban figyelemre méltó, ám éppen azért, mert eszmecserére és vitára is serkent. A tanulmánykötet egyik szerkesztôjeként, nem mellesleg a kötet vezetô tanulmányának írójaként is, recenziód néhány megállapítására fogok reagálni a tisztázó eszmecsere szándékával.

Néhány kérdés. - Recenziód következô észrevételeihez, megállapításaihoz kapcsolom a magam kommentárjait. Indításképpen kérdéseimet fogalmazom meg: Könyvünk vajon valóban hagiográfia lenne? - Karácsony Sándor életmúvével foglalkozva elemzéseink egyfajta belterjesség jegyében fogant kultuszszövegek? - Homálygerjesztô buzgalmunkban ráadásul még történetietlenek is vagyunk, hiszen nem is pusztán a prezentizmus vétkébe estünk, mert ezenközben a múltba vetített kérdéseinket, illetve válaszainkat a „klasszikus örök érvény” állításaival is elnehezítjük? - Kötetünk alaphangja tehát történetietlen plusz nyugatellenes, sôt mi több: provinciálisan bezárkózó is lenne? - És a recenziód végén olvasható kérdésben rejlố állításod: kötetünk számodra azt mutatta, hogy - kérdezed - a felvilágosodás felszámolásának pszichológiai jelszórendszere kezd kialakulni a szövegeinkben?

Rövid, tömör válaszom ezekre a kérdésekre (állításokra/vélelmekre) az lehetne, hogy túldimenzionálod kötetünk szándékait, törekvéseit, állításait. Az Arany János-i „Gondolta a fene!” élces adomával itt le is zárhatnám levelemet. Egy rövid recenzióra persze nem illendố tanulmány terjedelmú választ adni, ám az Arany János-i karcos választ mégis szükségesnek tartom a következó gondolatmenettel kibontani, megmagyarázni.

Kötetünk létrejötte és koncepciója. - 2015. november 21-én a Csökmei Kör és a Magyar Pszichológiai Társaság (MPT) Pszichológiatörténeti Tagozata által rendezett konferencián azzal a problémával igyekeztünk szembenézni, hogy Karácsony Sándor 
társaslélektana a mai (magyar) pszichológia tükrében vajon milyen pszichológia lehet. Próbálkozásunk egyfelôl a lehetetlent kísértette, másfelôl - éppen a Csökmei Kör korábbi konferenciáinak témáira is tekintettel - szinte kézenfekvố is volt.

Konferenciánk azért kísértette a lehetetlent, mert a mai - s ezen belül a magyar pszichológia témáit, módszereit, elméleti és gyakorlati vonatkozásait illetôen számtalan összehasonlítási lehetôséget kínálhat.

Ugyanakkor kézenfekvő is volt konferenciánk témaválasztása. A Csökmei Kör mely Karácsony Sándor életmúve gondozására jött létre 1990-ben - éves konferenciáin Karácsony Sándor pedagógiájának különbözố részleteit, összefüggéseit, elágazásait, mai tanulságait tematizálta, ám természetesen úgy, hogy Karácsony Sándor társaslélektanáról is folyamatosan szó volt. Karácsony Sándor pedagógiája ugyanis társaslélektani alapokon nyugszik.

Konferenciánkon tehát egy sajátos perspektívaváltással ezt a kérdést tettük fel: ha Karácsony Sándor pedagógiáját ugyan nem is tesszük zárójelbe, mégis próbáljuk meg csak a társaslélektanát megvizsgálni - ez a társaslélektan a XXI. század pszichológiai tudása mérlegére helyezve vajon milyen pszichológia?

Kérdésünk azért is fontos, érdekes, ám szinte megválaszolhatatlan(nak tûnt), mert Karácsony Sándor életmúve 1952-ben (Karácsony Sándor halálával) lezárult. Az 1950-es évek társadalmi/politikai, de tudományos kor- és kórviszonyai miatt Karácsony életmúve szinte (majdnem) kitörlődött a magyar tudomány emlékezetéból, az emlékezetvesztés jószerivel az 1980-as évek végéig tartott, és bár a Csökmei Kör 1990 óta nagyon sokat tett Karácsony Sándor életmúve feltámasztására, a pedagógia terén nem is sikertelenül, a magyar pszichológia/pszichológusok körében ez korántsem történt meg ilyen eredménnyel.

A MPT Pszichológiatörténeti Tagozata vezetôjeként számomra tehát a konferencia igazi és nagy kihívása ez volt: Karácsony Sándor-emlékezetünk és a mai magyar pszichológiatörténet-irás milyen helyzetben van?

A 2015. novemberi konferencia egyfelől a konferencia-előadások, hozzászólások írott változata, másfelôl, bár ugyanarról szól(t), mégis másképpen, mert két múfajról van szó. A szó elszáll - szoktuk mondani -, az írás megmarad. (Ha elszálló szavainkat leírjuk/rögzítjük - így még esetleg az „örökkévalóságot” is becserkészhetjük.)

Konferenciánk egész napos, élénk, eleven diskurzus volt - kötetünk ennek (halvány) visszfénye. Ennek a sajátos fénytörésnek a következménye az is, amit Te (joggal) szóvá tettél: „bennfentes” utalások, rövid, nem kifejtett állítások teszik/tehetik problematikussá a szövegeink dekódolását.

A könyvszerkesztés bonyodalmai. - A kötet technikai korrektúrájáról, egységes formai meg nem szerkesztésérôl most nem is szólok, csak mintegy futólag megemlítem. Kötetünk ezért sajátos hibridállapotban maradt: megórizte a konferencia-elôadások sorrendjét, szerkezeti jellegét, ám elmaradt az az utómunkálat, amitôl kötetünk pszichológia felól adódó interpretációs arculata jobban kidomborodhatott volna. Ennek viszont nem a szerkesztôk nemtörôdömsége, netán lustasága volt az oka, hanem egy nagyon prózai tényezô: a kötet finanszírozásának szinte bénítóan limitált mivolta.

Tudománytörténeti emlékezetünk. - Ám akár a konferencia eleven, vibráló diskurzusait, akár ezek (halvány) visszfényeit, előadásaink szövegeit veszem figyelembe, egyként az a tanulságuk: Karácsony Sándor nyugtalanító jelenléte - és még nyugta- 
lanítóbb hiánya - tudománytörténeti emlékezetünk önreflexivitását serkentố erô. A konferencia résztvevôi, kötetünk tanulmányírói különösen, természetesen amellett érveltek/ érvelnek, hogy Karácsony Sándor-emlékezetünk ne halványuljon. Annál is inkább ezt mondjuk/írjuk, mert meggyőzoodésünk: Karácsony Sándor életmúve - s ennek szerves részét képezô társaslélektana - nem pókhálós múzeumi tudás, néhány idôs(ödô) és morcos múzeumốr rigolyás ragaszkodása a homályos „múlt” (netán tanulságos, de valójában fölösleges, noha mégis veszélyes, mert nyugatellenes, provinciális, sốt felvilágosodásellenes) rekvizitumaihoz.

Én pedig azt a következtetést vontam le mindezekből, hogy a magyar pszichológiatörténet is gazdagodhat, ha Karácsony Sándorban nemcsak az iskolateremtô pedagógust, hanem a XX. századi magyar pszichológia egyik figyelemre méltó múvelójét is látjuk. Azt a gondolkodót, aki a XXI. század elején is releváns életmúvével, bonyolultan összetett társaslélektani rendszerével szinte provokatív kihívást jelent(het) mind a pszichológiai tudás elméleti, mind pedig a leghétköznapibb életvilág gyakorlati problémáival foglalkozó szakemberek számára is.

A „provokáció(nk)" sikeres volt - hiszen a Te recenziód is a (magyar) pszichológia elméleti és gyakorlati alapkérdéseit feszegeti, mert abban talán egyetérthetünk: ezeket az alapkérdéseket időnként érdemes megvizsgálnunk. Karácsony Sándort mi afféle „katalizátornak" használtuk ezekhez a vizsgálatokhoz. A szigorú (értsd: kísérleti/empirikus) szaktudományos pszichológia mérlegén Karácsony Sándor pszichológiája = társaslélektana netán „könnyúnek” is található (magam is hajlok erre), ám ezt éppenséggel tudománytörténeti összefüggéseiben érdemes megítélnünk: a XX. századi századeló és elsố fele tudományos és egyetemi hatásai erôterében. Karácsony Sándor társaslélektana ugyanis a Wundt-féle néplélektan európai és magyar (mindenekelôtt Gombocz Zoltán) hatáskörében alakult ki, de nem kollektív pszichológiaként, hanem társas lélektanként: a „másik embert” mint relációs alapviszonyt tételezve. Ezért Karácsony Sándornál a „magyar észjárás” elemzése/vizsgálata sem kollektív mítoszgyártás, hanem a magyarul beszélô emberek társaslogikája és társaslélektana, tehát például szimbólumok, jelek fenomenológiája, értelmezése, ami ugyanakkor nincs ellentétben sem a nyelvi, grammatikai logikával, sem a kognitív pszichológiával - mint ezt kötetünkben (az általad is dicsért) Séra László-tanulmány kiválóan bizonyította is. Ám ez nem jelentette azt, hogy mi Karácsony Sándorból kognitív pszichológust szerettünk volna faragni, mert ez történetietlen aktualizálás lett volna. Karácsony társaslélektanában ugyanis mintegy benne van, de még nincs kibontva az a csontváz, ami a kognitív pszichológiában (is) majd életre kel - az ô társaslélektana még eleven (tehát többek között valóban beszélô) élô test: az élet- és értékvilág zavaró, ám éppen ettôl dinamikus és komplex fenomenológiai valósága. Ez az összetettség az, amitól tudománytörténeti/pszichológiatörténeti vizsgálódásra kiválóan alkalmas terep a Karácsony-féle társaslélektan.

Karácsony társaslélektana azonban attól is provokatív a mai tudományos/kognitív pszichológus számára, hogy nem reduktív - de ettôl még nem homályos, nem is tudománytalan. A szcientikus/kognitív pszichológia és pszichológus persze azt (is) gondolhatja, hogy a karteziánus materializmus (lenne) a pszichológia alapja - a kognitív pszichológiáé (talán) igen. Karácsony Sándor nem volt kognitív pszichológus - ebben nincs közöttünk vita. De ebból nem következik, hogy tudománytalan is, csak más paradigmában élt és gondolkodott. 
Paradigmák pluralitása. - Konferenciánk elôadói és kötetünk szerzôi a paradigmák pluralitását is reprezentálták, noha nem kétséges: Karácsony Sándor életmúvét mindegyikük figyelemre méltó teljesítménynek tartotta/tartja, ilyen vagy olyan szempontok szerint-Te is ezek közé tartozol. Vonatkozó publikációid is azt bizonyíthatják, hogy Karácsony Sándor nyelvfelfogását a mai pszicholingvisztika mérlegére helyezve említésre és elemzésre méltó gondolatokat találtál nála (Pléh, 2000, 486-487; 2011; 2014, 97-99), konferenciánkon történt hozzászólásodban ennek is hangot adtál kritikai észrevételeid mellett. Nem kétséges persze: pedagógus kollegáink némelyike a pszichológiában is harci terepet lát (különösen, ha mozgalmár hajlandóságú). A napi pedagógiai/oktatói-nevelối munka rutinjaiba netán belefáradó, de hivatásukhoz ragaszkodó pedagógusok a pszichológiában viszont inkább didaktikai segédeszközt keresnek - Karácsony Sándorban is ilyenféle erôforrást láttak és látnak. A mi konferenciánkon is jobbára ôk adták diskurzusaink vibráló alaptónusát, konferenciakötetünkben ebból sajnos alig maradt valami, ami mégis átszúrôdött, az valamiféle laza „mesének” látszott. Pszichoterápiával foglalkozó pszichológuskollegáink szintén ilyesfajta „meséket” adtak elô, csak ôk nem a pedagógiai gyakorlat, hanem a lélekgyógyászat bugyraiból tekintettek Karácsony Sándor útmutatásaira. A kutató pedagógus és pszichológus viszont inkább az empirikus vizsgálódásai és módszertani kérdései felől „használja” a pszichológiát, ezért óhatatlanul szigorúbban is mérlegeli a Karácsony-féle pedagógiai szociálpszichológia alkalmazásainak lehetôségeit. Különbözóek vagyunk - gúnyolódni ezen persze nem illik, kritizálni viszont nagyon is szabad. A módszertani igényesség mégsem pótolhatja a kreatív gondolatokat és víziókat, a víziók viszont módszertani keretezés nélkül csak prófétai kinyilatkoztatások maradnak. Karácsony Sándor nem volt próféta, ám valóban: már életében kultusz övezte - nagyhírü professzor volt (Kontra, 2003). Konferenciánk tudománytörténeti koncepcióját éppen ezért ebben a kérdésben tudom összefoglalni:

Kultusz és/vagy kiegyensúlyozott emlékezés? - Konferenciánk és kötetünk is tehát azzal a kérdéssel is igyekezett szembenézni, hogy a tudománytörténeti emlékezetvesztés, a különbözô emlékezeti egyensúlytalanságok (pl. kultuszok) „terápiája” lehetséges-e? A némileg pikírt megjegyzésedet - azt, hogy én az „elfeledett hagyomány és diszkontinuitás ostorozója” volnék - tulajdonképpen vállalom, azzal a fontos kiegészítéssel: nem képzelem magam „ostornak”, írásaimban pedig igazából azért sem „ostorozok” semmit és senkit, mert az igazságosztó és ideologikus attitûd is hiányzik belôlem. Konferencia-elôadásomban és írott változatában is azonban valóban amellett érveltem/ érvelek, hogy az élettörténeti fogantatású tudomány- és pszichológiatörténet-írás feladata/funkciója: a helyreállító folyamatosság/ok föltárása, az elveszett adatok, összefüggések megtalálása, s mindezek visszahelyezése a szakmai diskurzusok nyilvános tereibe. Az ilyenfajta tudománytörténeti „terápiás” munkálatokra Karácsony Sándor életmúve és az életmú utókora (sorsa/percepciója) kiváló lehetôségeket kínál/t.

Szakrális és szekuláris. - Karácsony Sándor életmúvével foglalkozva (akár tetszik, akár nem) a szakralitás és a szekularizáció problémáira is ki kell térnünk. Te is ezt tetted (nem különösebben lelkesen, inkább vonakodva), ezért most én is reflektálok észrevételeidre, noha magam is vonakodom ettôl. Ezért a szakrális és/vagy szekuláris élet- és értékvilág pszichológiai problémáira itt és most nem térek ki, ám mégis kénytelen vagyok jelezni: nem igazán érted Karácsony Sándort (és kötetünk ide vonatkozó intencióit), ha a „felvilágosodás felszámolásának pszichológiai jelszórendszerét” vé- 
led kiolvasni akár Karácsony, akár a mi szövegeinkből. Karácsony nagyon egyszerúen (mondhatnám: a természetes észjárás szerint) gondolkodott, s talán éppen emiatt ma már mi nehezebben is értjük. Karácsony az ésszel élô és alkotó embereket szerette. Azt tartotta: „ha le van támasztva a szoba sarkába valami botféleség, amirôl nem tudjuk, hogy micsoda, kétféle az okos magaviselet: 1 . Ha nem izgat, belenyugszom, hogy akármi is az, jó helyen van, aki odatette, tudta mit tesz oda, békén maradok a bottól, és békén hagyom. 2. Fölöttébb izgat mi az, kíváncsi vagyok, odamegyek és megnézem. Ha azonban kíváncsi vagyok, és mégse nézem meg, ez buta és lusta magatartás. Az ilyennek nincs joga meg nem nézni. Annak azonban, aki elhiszi, hogy rendben van, minden joga megvan meg nem nézni” (Heltai, 2009, 82).

Az tehát valóban úgy van, hogy Karácsony az euro-amerikai modern ember egyoldalú és narcisztikus racionalizmusától ódzkodott, „betegesnek” és „önzônek” vélte. Az egészséges szkepszist ugyan minden tudásunk alapjának tartotta, de a hitetlen miérteket, amelyek még a „tudhatatlant is tudni akarják”, már negatívumnak, az ész önmagába hulló formátlanságának tartotta (Karácsony, 1942, 425).

Azt gondolom, hogy ez bölcs észjárás. Be nem láthatom: hol itt a „felvilágosodás felszámolásának pszichológiai jelszórendszere”?

Lezár(hat)atlan kérdések özöne. - Nyilvánvalóan problémák özönét gerjeszti az iménti gondolatmenet is. Karácsony egyfelôl valóban nagyon egyszerûen, a mindennapi észjárással is könnyen belátható módon érvel, ám másfelôl mégis igencsak szofisztikált módon teszi ezt. Hiszen Karácsony sajátos egyensúlyozó, szinte akrobatikus gondolati múveleteket hajt végre akkor, amikor például az egészséges szkepszist a hittel szeretné kibékíteni. Mennyire a lehetetlent kísértô próbálkozás ez? Éppenséggel nem inkább arról lenne szó: jobb, ha a tudomány számára nem húzunk határokat - majd kiderül: meddig jutunk! Önkorlátozó módon azonban ne húzzunk határt. A határhúzás tehát valójában „kizáró” - nem bölcs gondolat. Valóban nem bölcs? A Karácsony Sándor-i érv itt már persze óhatatlanul archetípusos: bibliai...

Nem folytatom. ${ }^{1}$

$*$

Mindezekrôl a problémákról (is) tehát érdemes eszmét cserélnünk. Ezt megtettük szóban a konferenciánkon (ahol Te is ott voltál, akkor is szóltál), megtettük a konferenciakötetünkben (azok, akik megírták előadásaikat, hozzászólásaikat) - és megtettük most itt, a Magyar Pszichológiai Szemle virtuális/digitális (és papíralapú) lapjain is. Nem beszélve az egyéb alkalmakról, például kötetünk Irodalmi Lapozgatós bemutatásáról (2018. október 25-én), ahol szintén kiváló eszmecserét folytathattunk, a jelenlévó (talán nem csak bennfentes) érdeklődook - és nem mellesleg a magunk - épülésére is. Én ezt így tanultam Tóled (is) - még egyetemistaként, többek között pszichológiatörténeti kurzusodon is.

A régi barátsággal üdvözöllek: Lányi Gusztáv (ELTE TáTK)

\footnotetext{
Nem folytatom, de itt (a lábjegyzetben, néhány szó erejéig) mégis meg szeretném köszönni Nagy Jánosnak, pszichológuskollegámnak és barátomnak, kiváló észrevételeit, amelyekkel hozzásegített e levél gondolatmenetei pontosabb és árnyaltabb megfogalmazásaihoz. Éppen azzal segített sokat, hogy vitatkozunk/beszélgetünk - ezt tesszük már egyetemista korunk óta.
} 


\section{IRODALOM}

Heltai Miklós (2009). Egy tanár és egy osztály története egyik tagja felôl nézve. In Karácsony Sándor a pedagógus. Karácsony Sándor Múvelôdési Társaság VIII. számú füzete (pp. 43-95). Földes - Változatlan utánnyomás: 2010-ben. - Ennek az emlékiratnak a szerzôje, idôsebb Heltai Miklós (1909-1989), édesapja a Karácsony Sándor és a magyar pszichológia c. kötet(ünk) társszerkesztôjének. (Ez is egy apró filológiai adat a „bennfentességhez”...)

Karácsony Sándor (1942). Ocsúdó magyarság. Szokásrendszer és pedagógia. Budapest: Exudus Könyvkiadó. - 2. kiadás: Budapest: Széphalom Könyvmúhely, 2002.

Kontra György (2003). Karácsony Sándor, a nagyhíú professzor. Budapest: BIP - 2. kiadás: FöldesBudapest, Karácsony Sándor Múvelődési Társaság-Gondolat Kiadó, 2009.

Pléh Csaba (2000). A lélektan története. Budapest: Osiris Kiadó

Pléh Csaba (2011). Karácsony Sándor nyelvfelfogása és a mai pszicholingvisztika. Iskolakultúra, 8-9, 135-145.

Pléh Csaba (2014). A pszicholingvisztika története. In Pléh Csaba, \& Lukács Ágnes (szerk.), Pszicholongvisztika (pp. 3-116). Budapest: Akadémiai Kiadó.

Pléh Csaba (2018). Karácsony-kultusz és a pszichológia története. Magyar Pszichológiai Szemle, 2, 350-352. 